\title{
Ab initio study of structural, electronic, and thermal properties of $\operatorname{Ir}_{1-x} \mathrm{Rh}_{x}$ alloys
}

\author{
S. Ahmed $]^{*}$ M. Zafar, M. Shakil, M.A. Choudhary \\ Simulation Laboratory, Department of Physics, The Islamia University of Bahawalpur, Bahawalpur 63100, \\ Pakistan
}

Received August 4, 2014, in final form October 31, 2014

\begin{abstract}
The structural, electronic, mechanical and thermal properties of $\operatorname{Ir}_{1-x} \mathrm{Rh}_{x}$ alloys were studied systematically using ab initio density functional theory at different concentrations $(x=0.00,0.25,0.50,0.75,1.00)$. A Special Quasirandom Structure method was used to make alloys having FCC structure with four atoms per unit cell. The ground state properties such as lattice constant and bulk modulus were calculated to find the equilibrium atomic position for stable alloys. The calculated ground state properties are in good agreement with the experimental and previously presented other theoretical data. The electronic band structure and density of states were calculated to study the electronic properties for these alloys at different concentrations. The electronic properties substantiate the metallic behavior of alloys. The first principle density functional perturbation theory as implemented in quasiharmonic approximation was used for the calculation of thermal properties. We have calculated the thermal properties such as Debye temperatures, vibration energy, entropy, constant-volume specific heat and internal energy. The ab initio linear-response method was used to calculate phonon densities of states.
\end{abstract}

Key words: electronic, structural and thermal properties of Platinum group metals

PACS: $61.50 f, 71.15 \mathrm{Mb}, 71.20 \mathrm{Be}$

\section{Introduction}

Platinum group metals are promising candidates for a wide range of applications. Iridium (Ir), Rhodium (Rh) belong to this group and are the rarest elements found in the earth's crust. Their incredible catalysis activity increases research interest in these rare elements [1]. Iridium has high density, high melting temperature and the highest corrosion resistance. Its thermal stability at high temperatures and the highest shear modulus at room temperature made it a superior metal [2]-4]. It has been investigated for carbon materials protective coatings [5], heavy-metal-ion sensors [6] and Re-rocket thrusters [7] applications. It is broadly used in organic chemistry for hydrogenation, hydroformulation, hydroboration, hydrosilylation, cycloadditions [8] and oxidation reactions for catalytic converters in automobiles. It remains a metal of high interest due to its unique properties for the scientific community [10, 11] during the past decades. Binary intermetallic alloys that contain a transition metal display interesting electronic, structural, optical and thermal properties. Recently, Ir- and Rh-base alloys are known as ultra-high temperature materials due to their high-melting temperatures, good high-temperature strengths and good oxidation resistances [12,-14]. Rh-base alloys have better oxidation resistance, lower density, lower thermal expansion coefficient and higher thermal conductivity than Ir-base alloys. These properties make Rh-base alloys more promising for ultra-high temperature gas turbine applications. To our knowledge, theoretical and experimental calculation are performed for Ir, Rh and their alloys with other metals but neither theoretical nor experimental calculations are available for Ir-Rh alloys. These alloys provide a class of systems exhibiting unique mechanical properties that make them attractive for structural applications [15]. In recent years, Ir-base super-alloys with good high-temperature properties have been

\footnotetext{
*E-mail: shabir_sehr@hotmail.com
} 
developed as promising candidates for ultrahigh-temperature applications to replace the traditional Nibase super-alloys, which have limited temperature capabilities due to the rather low melting point of $\mathrm{Ni}[16$ [18]. These alloys are promising materials for high temperature and pressure applications, and currently they are being examined for use in diesel engine turbocharger rotors, high-temperature die and molds, hydroturbines, and cutting tools [19]. Due to the improvements in simulation techniques in material science, it is now possible to study materials from bulk to nano scale devices [20]. The use of first principles calculations offers one of the most powerful tools for carrying out theoretical studies of a number of important physical and chemical properties of condensed matter with great accuracy [21, 22]. Electronic structure simulations based on density-functional theory (DFT) [23, 24] have been instrumental to this revolution, and their application has now spread outside a restricted core of researchers in condensed-matter theory and quantum chemistry, involving a vast community of end users with very diverse scientific backgrounds and research interests. The knowledge of thermal properties is essential for the study of mechanical properties [25]. To the best of our knowledge, there are no experimental and other theoretical data for comparison, so we consider the present results as a predictive study for the first time, which still awaits an experimental confirmation.

\section{Computational method}

The first principles investigation was performed using a pseudo-potential plane wave (PP-PW) method as implemented in QUANTUMES ESPRESSO [26]. Special Quasirandom Structure method proposed by Zunger and coworkers [32] was used to make FCC structure with four atoms per unit cell alloys. SQSs are specially designed for a small supercell that is computationally feasible for DFT calculations. Vanderbilt ultra soft pseudo-potential parameterized by Perdew and Zunger [27, 28] was used for calculations. We used ultrasoft Vanderbilt formalism with local density approximation (LDA) [29] for the exchange correlation energy of electrons. The special $k$-points were integrated to the sampled Brillouin zone using the Monkhorst-Pack method [31]. A special $k$-points mesh of $14 \times 14 \times 14$ was used to produce an irreducible Brillouin zone. Pseudo-wave functions were expanded in a plane wave basis set using the cut-off energy of 25 Ry for all concentrations. The chosen cut-off energy and $k$-point mesh ensure convergence with an accuracy of $10^{-6}$ Ry. Density Functional Perturbation Theory (DFPT) and Quasi Harmonic Approximation (QHA) code developed by Baroni et al. [26] were used to investigate the phonon density of states and thermal properties from optimized structure. The dynamical matrices at arbitrary wave vectors were obtained using the Fourier transformation-based interpolations to calculate thermal properties. A $12 \times 12 \times 12 q$ point mesh was implemented to obtain dynamical matrices of force constants in the irreducible Brillouin zone at $\Gamma$ point. The linear response approach method was used to obtain the curves of phonon density of states within the framework of DFPT [26] as implemented in Quantum ESPRESSO. The parameters such as cell dimension, energy cut-offs and the $k$-points used in the study were obtained from their respective convergence tests. These convergence parameters provide a fast way toward an optimized structure.

\section{Results and discussion}

\subsection{Structural properties}

We have found the ground state properties of $\operatorname{Ir}_{1-x} \mathrm{Rh}_{x}$ alloys at $x=0,0.25,0.5,0.75$, and 1.00. The total energy per unit cell was computed at various lattice parameters to find the equilibrium lattice constant. The equilibrium lattice constant was found by minimizing the total energy of system. Murnaghan's equation of state was used to evaluate the optimized lattice constants and bulk moduli [33].

The structural parameters i.e., lattice constants and bulk modulus for pure Ir, Rh and their alloys were calculated and reported in table 1 along with experimental and other theoretical results. The optimized lattice curves for $\operatorname{Ir}_{1-x} \mathrm{Rh}_{x}$ alloys at $x=0,0.25,0.5,0.75$, and 1.00 are shown in figure 2 Figure 1 shows the variation of lattice constants and bulk modulus for $\operatorname{Ir}_{1-x} \mathrm{Rh}_{x}$ evaluated using Vegard's law. It is seen 
Table 1. Calculated lattice parameters and bulk modulus of $\operatorname{Ir}_{1-x} \mathrm{Rh}_{x}$ alloys compared with experimental and other theoretical results at $x=0,0.25,0.5,0.75$, and 1.00 .

\begin{tabular}{|c|c|c|c|c|c|c|}
\hline Composition & \multicolumn{2}{|c|}{ Lattice constant (Angstrom) } & \multicolumn{3}{c|}{ Bulk modulus (Gpa) } \\
\hline$x$ & This work & Experimental & $\begin{array}{c}\text { Other } \\
\text { calculation }\end{array}$ & This work & Experimental & $\begin{array}{c}\text { Other } \\
\text { calculation }\end{array}$ \\
\hline \hline 0.00 & 3.831 & $3.84^{a}$ & $3.88^{b}$ & 360 & $355^{e}$ & $386^{g}$ \\
0.25 & 3.81394 & & & 337.375 & & \\
0.50 & 3.80373 & & & 315 & & \\
0.75 & 3.79589 & & & 294.5 & & \\
1.00 & 3.792 & $3.803^{c}$ & $3.847^{d}$ & 269.5 & $268.7^{f}$ & $259.6^{h}$ \\
\hline
\end{tabular}

${ }^{a}$ reference [34], $\quad{ }^{b}$ reference [35], $\quad{ }^{c}$ reference [36], $\quad{ }^{d}$ reference [37],

${ }^{e}$ reference [38], $\quad f$ reference [39], $\quad h$ reference [40], $\quad{ }^{g}$ reference [41].
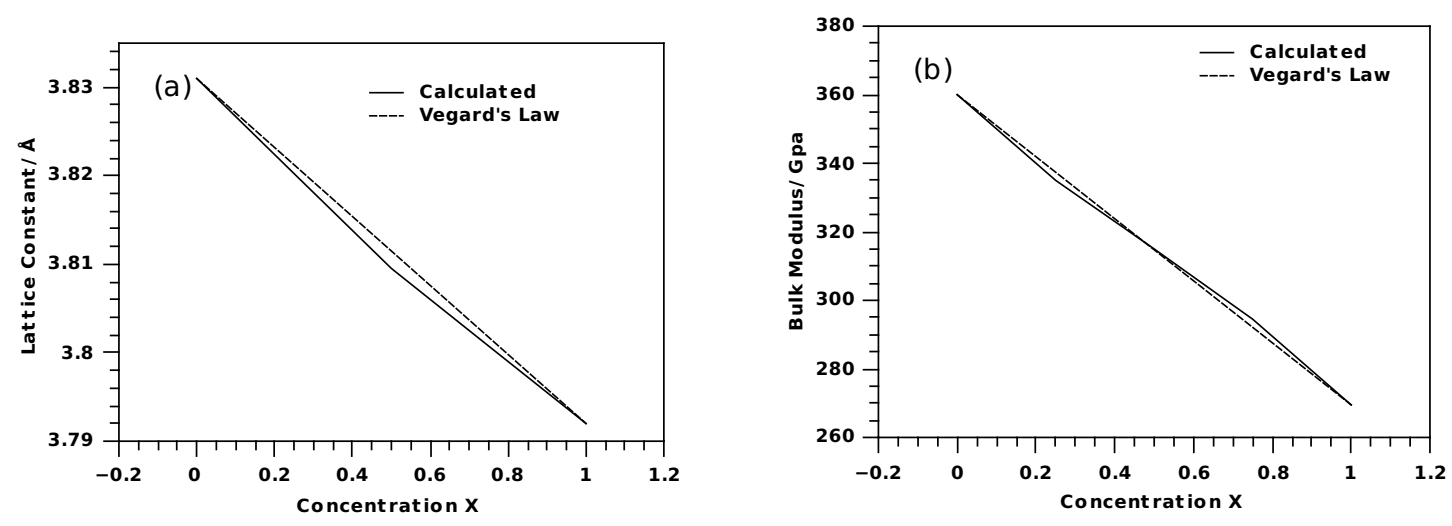

Figure 1. Calculated lattice parameters and bulk modulus in comparison with Vegard's law at experimental values for $\operatorname{Ir}_{1-x} \mathrm{Rh}_{x}$ alloys: (a) lattice constant, (b) bulk modulus.

that with the change of Rh concentration in $\operatorname{Ir}_{1-x} \mathrm{Rh}_{x}$ alloys, the lattice constant and bulk modulus show a considerable change from Vegard's law which may be due to the lattice mismatch in these alloys.

The calculated results are compared with experimental and other theoretical results for pure Ir and Rh. However, the experimental or theoretical results for their alloys are not yet available in the literature for comparison. These calculations may be a prediction for researchers for future. The values of the calculated lattice constant and the bulk modulus for $\operatorname{Ir}_{1-x} \mathrm{Rh}_{x}$ alloys turned out to decrease with an increase of the Rh concentration.

\subsection{Electronic properties}

Electronic properties depend on the electronic configuration in materials, particularly on the existence of prohibited regions of energy and on the magnitude in their electronic excitation spectra. Detailed band-structure calculations are needed to understand the electronic properties of any material. Thus, the band structures for $\operatorname{Ir}_{1-x} \mathrm{Rh}_{x}$ along various high symmetry directions were calculated at equilibrium lattice constants. The electronic band structures are shown in figure 3 The Fermi level for the band structure was set to be $0 \mathrm{eV}$. It can be seen from figure 3 (a)-(e) that electronic bands for all concentrations overlap at the Fermi level. The electronic structures calculated for different concentrations clearly show the metallic nature of the materials since the energy bands intersect at the Fermi level. Conductivity in Ir metal is dominated by overlapping of $s, p$ and $d$ bands.

For Rh metal, the conductivity is dominated by a narrow $d$-band with some empty states overlapped by a broad free electron $s$-band. Their alloys show a metallic nature due to $s, p, d$ of Ir atoms and $s, d$ of Rh atoms bands overlapping. So, these alloys lead to archetypical transition metals, in which a narrow $d$ - 

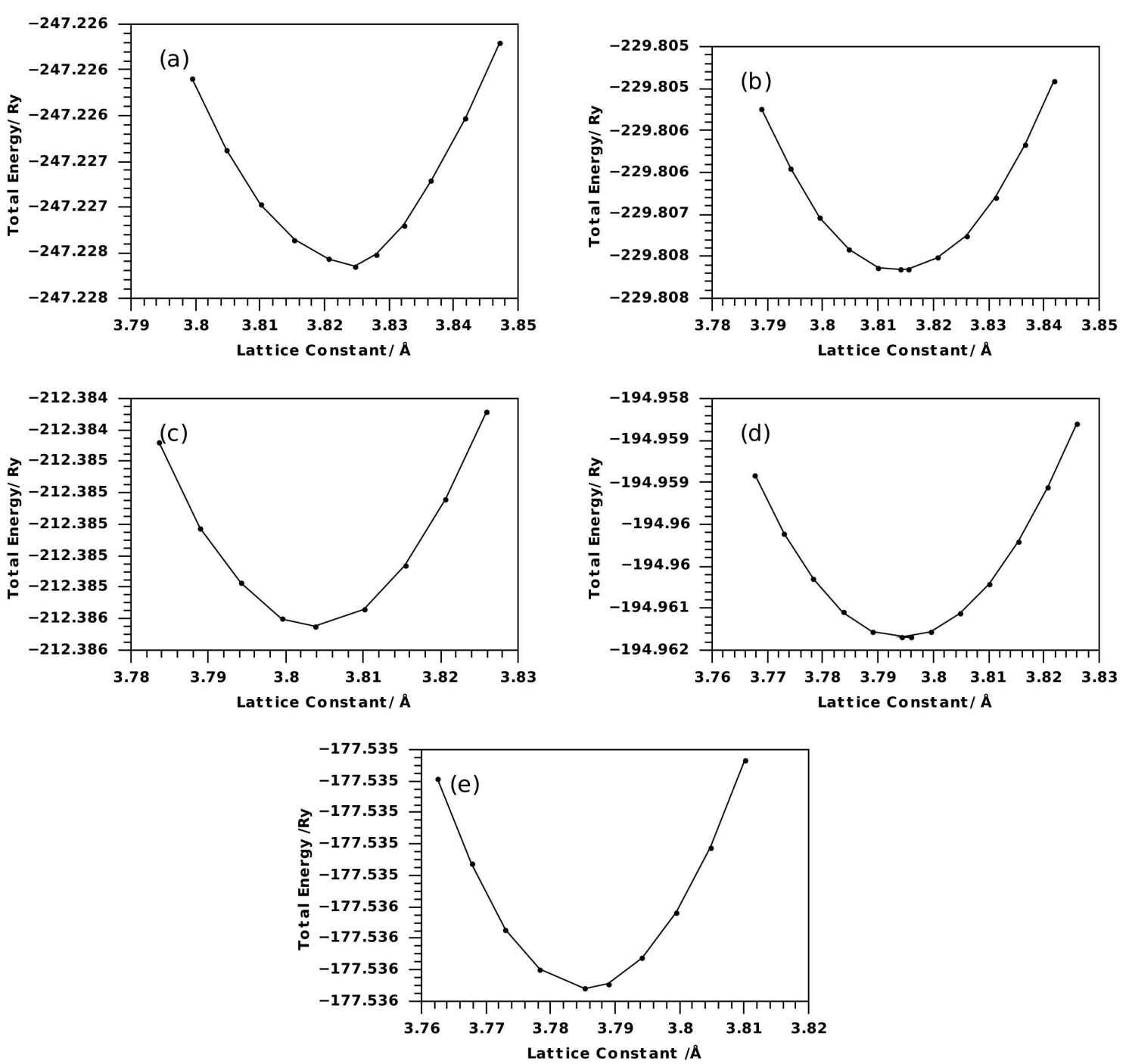

Figure 2. Structural optimization plots for $\operatorname{Ir}_{1-x} \mathrm{Rh}_{x}$ alloys: (a) at $x=0.00$, (b) at $x=0.25$, (c) at $x=0.50$, (d) at $x=0.75$ and (e) at $x=1.00$ concentrations.

band containing some empty states was overlapped by a broad free-electron like $s$-band which dominated the conductivity [42].

The calculated electronic band structures along the principal symmetry directions are presented in figure 3 (a)-(e). The overall band structure shows a similar metallic nature. The main hybridization remains between $d$ bands of both Ir and Rh when mixed in order to form their alloys. The Fermi energy decreases with an increase of $\mathrm{Rh}$ percentage in $\mathrm{Ir}_{1-x} \mathrm{Rh}_{x}$ alloys. The calculated electronic band structure is in good agreement with the previous result for pure Ir and Rh 43 44]. From the calculated electronic band structure for $\operatorname{Ir}_{1-x} \mathrm{Rh}_{x}$ alloys, it can be seen that the band overlapping increases with Rh concentration which causes a decrease of resistivity with $\mathrm{Rh}$ concentration [45].

The density of states plays an essential role in studying many physical properties. Total energies of material can be calculated from the knowledge of the density of states. The number of electrons within the Fermi surface can be used to determine the nature of materials. The Fermi energy is determined by the Density of States (DOS) which provides information on the Fermi energy level. To further study the nature of electronic band structure, we have also calculated the total and partial DOS for these alloys for different concentrations at an ambient pressure and presented them in figure 4(a)-(e). In figure 4 (a), for pure Ir, the lowest lying bands were due to $s, p$ states and the higher energy states were mainly due to 
$d$ states, and the conductivity was dominated by $s, p$ and $d$ hybridization states. In case of $\operatorname{Ir}_{0.75} \mathrm{Rh}_{0.25}$ in figure 4 (b), the bottom state of the valence band was dominated with $s, p$ states of Ir and Rh $s$ state. The upper valance band region was dominated with Ir $d$ state with some contribution of other states. In figure 4 (c), with $\operatorname{Ir}_{0.50} \mathrm{Rh}_{0.50}$, the lowest part of the valance band was mostly contributed by $s$ state of both metals and Ir $p$ state but the higher energy level was dominated by a broad contribution of $d$-states of these metals with little part of other states. In figure 4 (d), for $\operatorname{Ir}_{0.25} \mathrm{Rh}_{0.75}, s, p$ states of Ir and Rh $s$ state for this alloys dominated the bottom of the valence band. In the upper band, Rh $d$ state was much wider than the Ir $d$ states. In figure 4 (e), with pure Rh, the bottom valence levels were mostly dominated by $s$ states but the higher valence band was dominated with $d$ states.
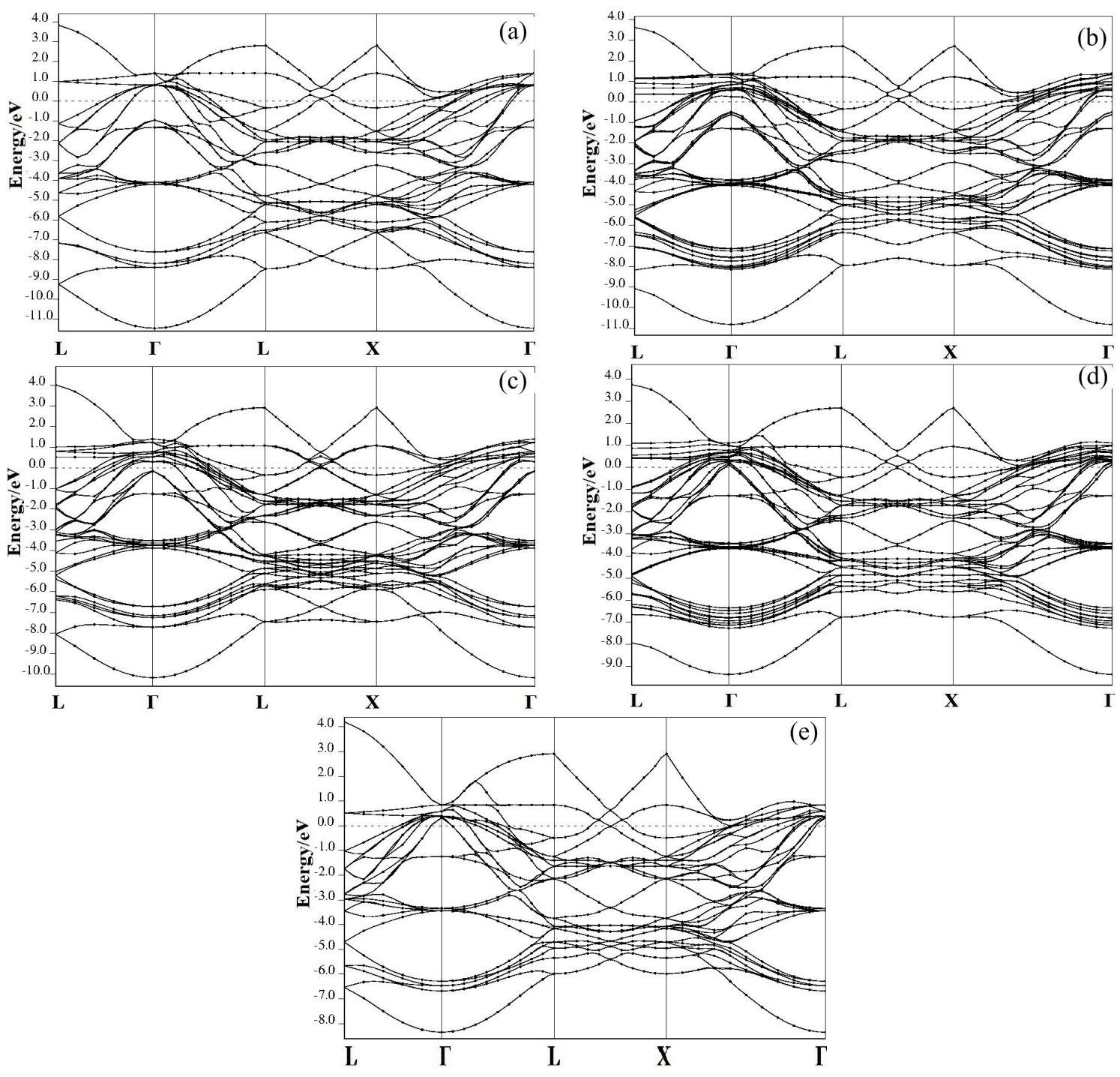

Figure 3. Calculated band structures for $\operatorname{Ir}_{1-x} \mathrm{Rh}_{x}$ alloys: (a) at $x=0.00$, (b) at $x=0.25$, (c) at $x=0.50$, (d) at $x=0.75$ and (e) at $x=1.00$ concentrations.

From the analysis of the band structure of $\operatorname{Ir}_{1-x} \mathrm{Rh}_{x}$ alloy, it was observed that, at different concentrations of these metals, the band structure shows a similar behavior that differs from each other mainly by the energy level of each band relative to the Fermi level. In pure Ir, the conductivity was mostly dominated by $s, p$ and $d$ hybridization but for pure Rh, the conductivity was prominent with $s$ and $d$ overlapping. The electronic energy density of states are compared with the previously reported result for cubic Ir and Rh 46 47]. When these metals were mixed to make alloys, strong hybridization between 

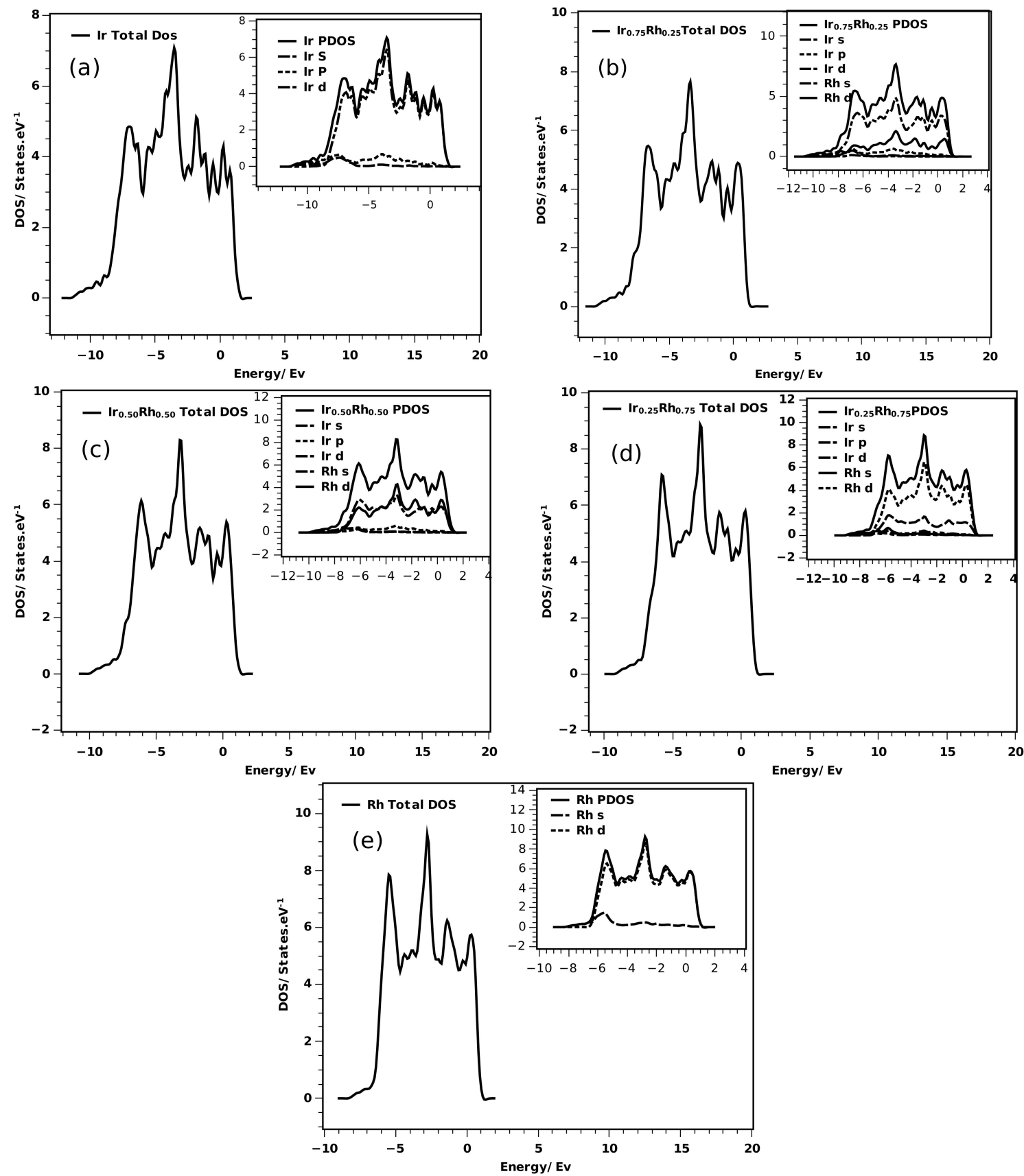

Figure 4. Density of states for $\operatorname{Ir}_{1-x} \mathrm{Rh}_{x}$ alloys: (a) at $x=0.00$, (b) at $x=0.25$, (c) at $x=0.50$, (d) at $x=0.75$, and (e) at $x=1.00$ concentrations.

the Ir and Rh $d$ states with small contribution of $s$ states dominated the conductivity. Ir has a lower electronic DOS than Rh at the Fermi level and it increases with an increase of Rh concentration in the alloy. The material having a lower electronic DOS at the Fermi level often characterizes a more stable structure 48, 49. Thus, Ir is a more stable structure than $\mathrm{Rh}$ and it decreases with Rh concentration. 


\subsection{Thermal properties}

Thermal properties of metals are of interest below the melting temperature. We have used a quasiharmonic approximation and phonon density of states to obtain thermal properties. Helmholtz free energy $\Delta F$, internal energy $\Delta E$, entropy $S$ and constant-volume specific heat $C_{v}$, at zero pressure are calculated. Phonon DOS has a strong impact on thermodynamic properties. The electron excitation becomes
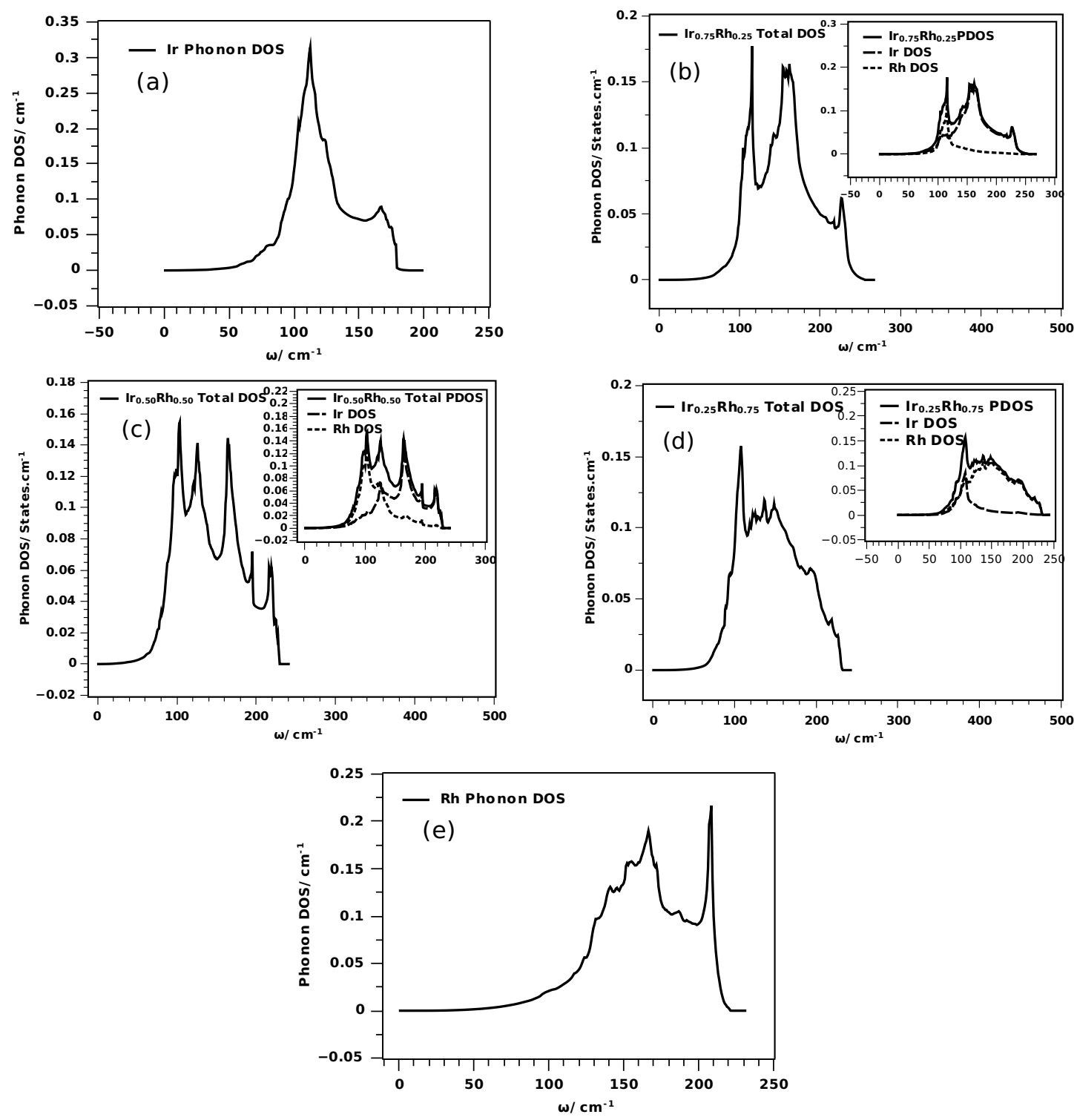

Figure 5. Phonon density of states for $\operatorname{Ir}_{1-x} \mathrm{Rh}_{x}$ alloys: (a) at $x=0.00$, (b) at $x=0.25$, (c) at $x=0.50$, (d) at $x=0.75$, and (e) at $x=1.00$ concentrations.

easier with higher phonon DOS [50]. Figure 5 depicts the phonon density of states of $\operatorname{Ir}_{1-x} \mathrm{Rh}_{x}$ alloys with different concentrations. The total phonon DOS for pure Ir was shown in figure 5 (a) and has a maximum DOS at frequency $112.5 \mathrm{~cm}^{-1}$. In figure 5 (b), two higher peaks in phonon DOS occur, first peak is dominated by $\mathrm{Rh}$ at frequency of $115.5 \mathrm{~cm}^{-1}$ and the second was due to Ir atoms at $162 \mathrm{~cm}^{-1}$ frequency. In figure 5 (c), three high peaks for phonon density of states occurs at a frequency of $103.5 \mathrm{~cm}^{-1}, 126 \mathrm{~cm}^{-1}$, $164.25 \mathrm{~cm}^{-1}$ which are due to movements of $\mathrm{Rh}$, Ir and $\mathrm{Rh}$ and Ir atoms, respectively. In figure 5 (d), the contribution of total phonon DOS was dominated by Ir and Rh atoms at low frequency of $108 \mathrm{~cm}^{-1}$. Con- 
versely, phonon density of states is mainly dominated by Rh atoms after this frequency. In figure 5 (e), for pure Rh, two higher peaks occur in phonon DOS, the first peak is dominated mainly at $155.25 \mathrm{~cm}^{-1}$ frequency and the second peak with frequency $166.5 \mathrm{~cm}^{-1}$.

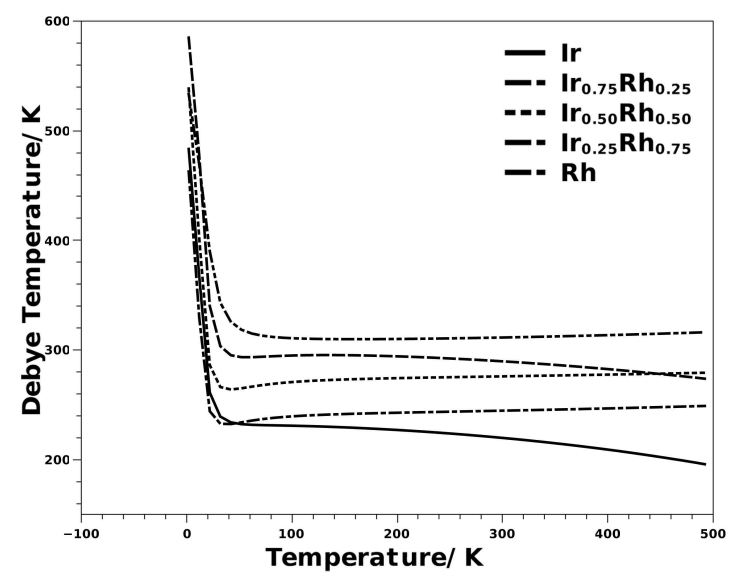

Figure 6. Debye temperature variation with temperature for $\operatorname{Ir}_{1-x} \mathrm{Rh}_{x}$ alloys at $x=0.00,0.25,0.50$, $0.75,1.00$.

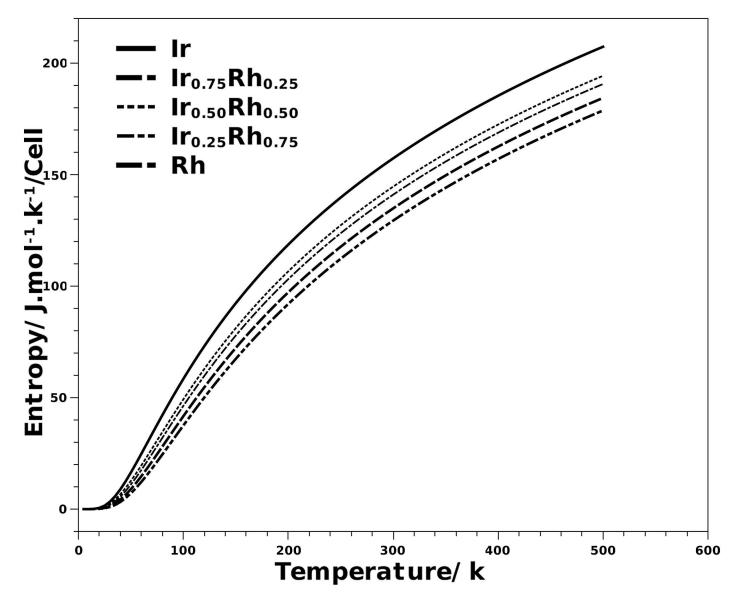

Figure 8. Entropy variation with temperature for $\mathrm{Ir}_{1-x} \mathrm{Rh}_{x}$ alloys at $x=0.00,0.25,0.5,0.75$, and 1.00 .

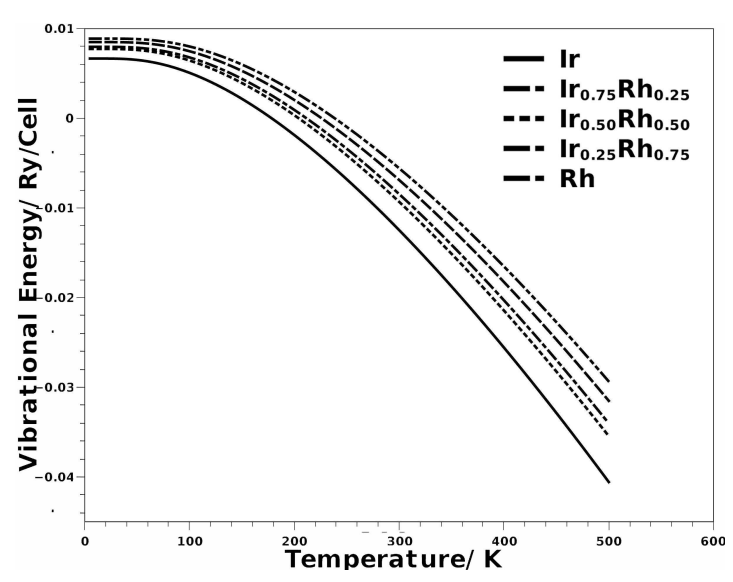

Figure 7. Vibration energy variation with temperature for $\operatorname{Ir}_{1-x} \mathrm{Rh}_{x}$ alloys at $x=0.00,0.25,0.50$, 0.75 , and 1.00 .

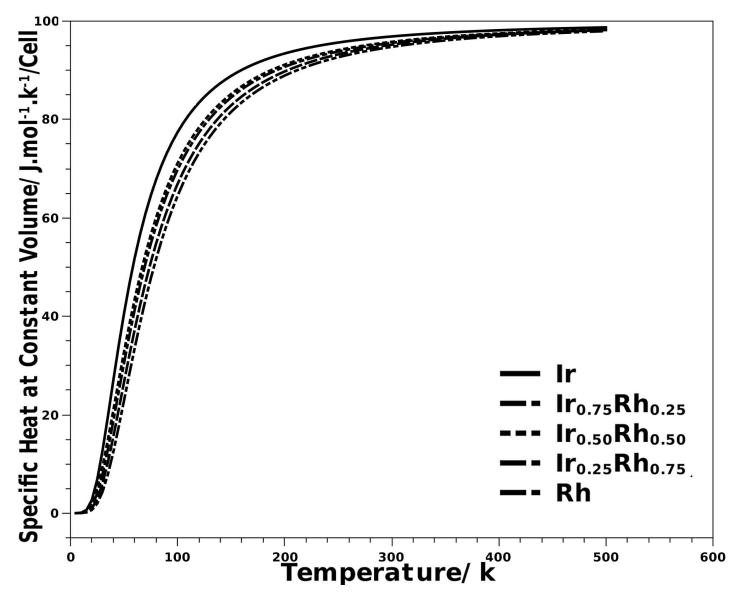

Figure 9. Specific heat at a constant volume variation with temperature for $\operatorname{Ir}_{1-x} \mathrm{Rh}_{x}$ alloys at $x=$ $0.00,0.25,0.50,0.75$, and 1.00 .

To further study the thermal properties, the Debye temperatures, vibration energy, entropy, constantvolume specific heat and internal energy are plotted in figures $6-10$ for this alloy. Debye temperature determines the thermal characteristics of materials and it is closely related to many physical properties such as specific heat [51]. The materials with high Debye temperature are associated with higher thermal conductivity. The knowledge of thermal conductivity and melting temperature is essential for developing and manufacturing electronic devices [52 [53]. The Debye temperature plays an important role in the field of thermo-physical properties of materials. Debye temperature was maximum at 0-20 K, then it decreases rapidly and approaches a constant for higher temperature values. Entropy, constant-volume specific heat and internal energy values increase quickly at a lower temperature and becomes converged to constant values with high temperature as in figure 9. Vibration energy remains constant for low temperature and decreases inversely as temperature increases. Entropy, constant-volume specific heat de- 
creases with $\mathrm{Rh}$ concentration but increases for $\operatorname{Ir}_{0.50} \mathrm{Rh}_{0.50}$, then continues the decreasing behavior for further $\mathrm{Rh}$ concentration. The increasing behavior may be due to the maximum lattice mismatch at 50 percent concentration and these quantities decrease with the further increase in $\mathrm{Rh}$ amount. It is seen that the internal energy and vibration energy increases slightly with Rh concentration but decreases for $\mathrm{Ir}_{0.50} \mathrm{Rh}_{0.50}$ concentration and then continues to progress. From figure 7 it can also be seen that Rh has a greater vibration energy compared to Ir. However, entropy, constant-volume specific heat , internal energy, vibration energy and Debye temperature show a different behavior at 50 percent concentration which may be due to a greater lattice mismatch. High entropy possesses many attractive properties, such as high hardness [54], outstanding wear resistance [55], good fatigue resistance characteristics [56], excellent high-temperature strength [57], good thermal stability [58] and, in general, good oxidation and corrosion resistance [59]. These properties suggest a great potential in a wide variety of applications.

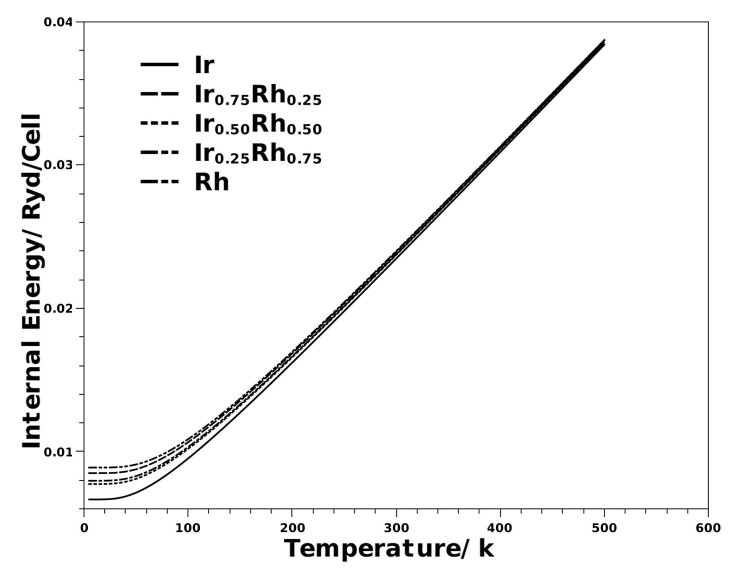

Figure 10. Internal energy variation with temperature for $\operatorname{Ir}_{1-x} \mathrm{Rh}_{x}$ alloys at $x=0.00,0.25,0.50,0.75$, and 1.00 .

Our calculated results of thermal properties for pure Ir and Rh are in good agreement with the previously published data [60,62]. There were no experimental or theoretical results for their alloys. Therefore, the results reported in this work will be predictive for future. From the above investigations of thermodynamics properties, it can be demonstrated that $\operatorname{Ir}_{1-x} \mathrm{Rh}_{x}$ with $x=0.5$ has a larger entropy and constant-volume specific heat due to a maximum lattice mismatch within the considered range of temperatures but the vibration energy and the Debye temperature were minimum for $x=0.5$.

\section{Conclusions}

The first principle method was employed to analyze the structural, electronic, mechanical, and thermal properties of the $\operatorname{Ir}_{1-x} \mathrm{Rh}_{x}$ alloys with a four atom unit cell. The pseudopotential scheme was used to study the alloys at different concentrations $(x=0.00,0.25,0.50,0.75,1.00)$. The following conclusions were drawn:

1. For the $\operatorname{Ir}_{1-x} \mathrm{Rh}_{x}$ alloys, by increasing $\mathrm{Rh}$ concentration, the lattice constant and the bulk modulus decrease. The variations in the calculated lattice constant and the bulk modulus are slightly different from Vegard's law.

2. In electronic properties, the electronic bands overlap at the Fermi level, and the Fermi energy decreases with an increase in Rh concentration but the band overlap increases. This is because $\mathrm{Rh}$ has a larger electronic conductivity than Ir. In pure Ir, a narrow $d$ state was overlapped by a broad free-electron $s$ and $p$ but pure Rh has an overlap between $s$ and $d$ only which dominates the conductivity in these metals. When Ir and Rh were mixed to form alloys, the main hybridization was between $d$ states with some contribution from other states. 
3. Thermodynamic properties such as phonon density of states, the Helmholtz free energy, the phonon contribution to the internal energy, the constant-volume specific heat, and entropy were calculated using the quasi-harmonic approximation. The minimum value of phonon density of states is for the alloy having $\operatorname{Ir}_{0.50} \mathrm{Rh}_{0.50}$ concentration. Debye temperature was maximum at $0-20 \mathrm{~K}$, then it decreases rapidly and approaches a constant for higher temperature values. Entropy, constantvolume specific heat and internal energy values increase quickly at a lower temperature and become converged to constant values with high temperature. Entropy, constant-volume specific heat decreases with $\mathrm{Rh}$ concentration but increases for $\operatorname{Ir}_{0.50} \mathrm{Rh}_{0.50}$, then continues a decreasing behavior for further Rh concentration. Vibration energy remains constant for low temperature and decreases inversely as temperature increases. It is seen that the internal energy and the vibration energy increase slightly with $\mathrm{Rh}$ concentration but decrease for $\operatorname{Ir}_{0.50} \mathrm{Rh}_{0.50}$ concentration and then continue to progress.

\section{References}

1. Yuan Y., Yan N., Dyson P.J., ACS Catal., 2012, 2, 1057; doi 10.1021/cs300142u

2. Savitskii E.M., Handbook of Precious Metals, Hemisphere, New York, 1989.

3. Cawkwell M.J., Nguyen-Manh D., Woodward C., Pettifor D.G., Vitek V., Science, 2005, 309, 1059; doi $10.1126 /$ science.1114704

4. Stevanović V., Sljivancanin $\quad$ Z., Baldereschi $\quad$ A., $\quad$ Phys. Rev. Lett., 2007, 99, 165501; doi $10.1103 /$ PhysRevLett.99.165501.

5. Mumataz K., Echigoya J., Hirai T., Shindo Y., Mat. Sci. Eng. A, 1993, 167, 187; doi 10.1016/0921-5093(93)90353-G

6. Kovacs G.T.A., Storment C.W., Kounaves S.P., Sens. Actuators B, 1995, 23, 41; doi 10.1016/0925-4005(94)01523-K

7. Hamilton J.C., Yang N.Y.C., Clift W.M., Boehme D.R., McCarty K.F., Franklin J.E., Metall. Trans. A, 1992, 23, 851; doi $10.1007 / \mathrm{BF} 02675562$

8. Yet L., Chem. Rev., 2000, 100, 2963; doi 10.1021/cr990407q

9. Progress in Inorganic Chemistry, vol. 28, Lippard S.J. (Ed.), Wiley, New York, 1981.

10. Rossen K., Angew. Chem. Int. Ed., 2001, 40, 24; doi 10.1002/1521-3773(20011217)40:24\%3C4611::AIDANIE4611\%3E3.3.CO;2-W

11. Ungváry F., Coord. Chem. Rev., 2002, 228, 61; doi 10.1016/S0010-8545(02)00051-6

12. Yamabe Y., Koizumi Y., Murakami H., Maruko T., Harada H., Scr. Mater., 1996, 35, 211; doi 10.1016/13596462(96)00109-1.

13. Yamabe Y., Koizumi Y., Murakami H., Maruko T., Harada H., Scr. Mater., 1997, 36, 393; doi 10.1016/S13596462(96)00408-3.

14. Miura S., Honmab K., Teradac Y., Sanchezd J.M., Mohria T., Intermetallics, 2000, 8, 785; doi 10.1016/S09669795(00)00012-1.

15. Iotova D., Kioussis N., Lim S.P., Phys. Rev. B, 1996, 54, 14413; doi 10.1103/PhysRevB.54.14413

16. Yamabe Y., Koizumi Y., Murakami H., Maruko T., Harada H., Scr. Mater., 1996, 35, 211; doi 10.1016/13596462(96)00109-1.

17. Yamabe Mitarai Y., Ro Y., Maruko T., Harada H., Metall. Mater. Trans. A, 1998, 29, 537; doi 10.1007/s11661-9980135-9

18. Yamabe-Mitarai Y., Harada H., Gu Y., Huang C., Metall. Mater. Trans. A, 2005, 36, 547; doi 10.1007/s11661-0050169-1

19. Mansour A.N., Dmitrienko A., Soldatov A.V., Phys. Rev. B, 1997, 55, 15531; doi 10.1103/PhysRevB.55.15531

20. Marzari N., MRS Bull., 2006, 31, 681; doi $10.1557 / \mathrm{mrs} 2006.177$

21. Okoye C.M.I., J. Phys.: Condens. Matter, 2003, 15, 5945; doi 10.1088/0953-8984/15/35/304

22. Bernick R.L., Kleinman L., Solid State Commun., 1970, 8, 569; doi 10.1016/0038-1098(70)90305-4

23. Parr R.G., Yang W., Density-Functional Theory of Atoms and Molecules, Oxford University Press, Oxford, 1989.

24. Dreizler R.M., Gross E.K.U., Density functional theory, Springer, Berlin, 1990.

25. Ivanov A.S., Katsnelson M.I., Mikhin A.G., Osetskii Yu.N., Rumyantsev A.Yu., Trefilov A.V., Shamanaev Yu.F., Yakovenkova L.I., Philos. Mag. B, 1994, 69, 1183; doi 10.1080/01418639408240188

26. Baroni S., Dal Corso A., Gironcoli S., Giannozzi P., Rev. Mod. Phys., 2001, 73, 515; doi 10.1103/RevModPhys.73.515

27. Ceperley D.M., Alder B.J., Phys. Rev. Lett., 1980, 45, 566; doi 10.1103/PhysRevLett.45.566

28. Perdew J.P., Zunger A., Phys. Rev. B, 1981, 23, 5048; doi 10.1103/PhysRevB.23.5048

29. Vanderbilt D., Phys. Rev. B, 1985, 32, 8412; doi 10.1103/PhysRevB.32.8412

30. Perdew J.P., Burke K., Ernzerhof M., Phys. Rev. Lett., 1996, 77, 3865; doi 10.1103/PhysRevLett.77.3865 
31. Monkhorst H.J., Pack J.D., Phys. Rev. B, 1976, 13, 5188; doi 10.1103/PhysRevB.13.5188.

32. Zunger A., Wei S.H., Ferreira L.G., Bernard J.E., Phys. Rev. Lett., 1990, 65, 353; doi:10.1103/PhysRevLett.65.353

33. Murnaghan F.D., Proc. Natl. Acad. Sci. USA, 1944, 30, 244; doi 10.1073/pnas.30.9.244

34. Mehl M.J., Papaconstantopoulos D.A., Phys. Rev. B, 1996, 54, 4519; doi 10.1103/PhysRevB.54.4519

35. Gong H.R., Scr. Mater., 2008, 59, 1197; doi 10.1016/j.scriptamat.2008.08.009

36. Singh H.P., Acta Crystallogr. A, 1968, 24, 469; doi 10.1107/S056773946800094X

37. Gómez J., Ding Y., Koitz R., Seitsonen A.P., Iann M., Theor. Chem. Acc., 2013, 132, 1350; doi 10.1007/s00214-0131350-Z

38. Simmons G., Wang H., Single Crystal Elastic Constants and Calculated Aggregate Properties, 2nd Edn., MIT Press, Cambridge, 1971.

39. Walker E., Ashkenazi J., Dacorogna M., Phys. Rev. B, 1981, 24, 2254; doi 10.1103/PhysRevB.24.2254

40. Niranjan M.K., Intermetallics, 2012, 26, 150; doi 10.1016/j.intermet.2012.03.049

41. Sa’adi H., Hamad B, J. Phys. Chem. Solids, 2008, 69, 2457; doi 10.1016/j.jpcs.2008.04.038

42. Hollister R.G., Darling A.S., Platin. Met. Rev., 1967, 11, No. 3, 94.

43. Ahuja B.L., Sharma V., Rathor A., Jani A.R., Sharma B.K., Nucl. Instrum. Methods Phys. Res., Sect. B, 2007, 262, 391; doi 10.1016/j.nimb.2007.05.029.

44. Noffke J., Fritsche L., J. Phys. F: Met. Phys., 1982, 12, 921; doi 10.1088/0305-4608/12/5/011

45. Powell R.W., Tye R.P., Woodman M.J., Platin. Met. Rev., 1962, 6, No. 4, 138.

46. Bannikov V.V., Shein I.R., Ivanovskii A.L., Solid State Commun., 2009, 149, 1807; doi 10.1016/j.sSc.2009.07.015

47. Sudhapriyanga G., Asvinimeenaatcia A.T., Rajeswarapalanichamy R., Iyakutti K., Acta Phys. Pol. A, 2014, 125, 29; doi 10.12693/APhysPolA.125.29

48. Xu J.H., Freeman A., Phys. Rev. B, 1990, 41, 12553; doi 10.1103/PhysRevB.41.12553

49. Xu J.H., Oguchi T., Freeman A.J., Phys. Rev. B, 1987, 35, 6940; doi 10.1103/PhysRevB.35.6940

50. Liang C.P., Gong H.R., Intermetallics, 2013, 32, 429; doi 10.1016/j.intermet.2012.09.014

51. Boucetta S., Zegrar F., Journal of Magnesium and Alloys, 2013, 1, 128; doi:10.1016/j.jma.2013.05.001

52. Newnham R.E., Properties of Materials: Anisotropy, Symmetry, Structure, Oxford University Press, New York, 2005.

53. Mattesini M., Magnuson M., Tasnádi F., Höglund C., Abrikosov I.A., Hultman L., Phy. Rev. B, 2009, 79, 125122; doi 10.1103/PhysRevB.79.125122

54. Chen S.T., Tang W.Y., Kuo Y.F., Chen S.Y., Tsau C.H., Shun T.T., Yeh J.W., Mater. Sci. Eng. A, 2010, 527, 5818; doi 10.1016/j.msea.2010.05.052

55. Chuang M.H., Tsai M.H., Wang W.R., Lin S.J., Yeh J.W., Acta Mater., 2011, 59, 6308; doi 10.1016/j.actamat.2011.06.041

56. Hemphill M.A., Yuan T., Wang G.Y., Yeh J.W., Tsai C.W., Chuang A., Liaw P.K., Acta Mater., 2012, 60, 5723; doi 10.1016/j.actamat.2012.06.046

57. Hsu C.Y., Juan C.C., Wang W.R., Sheu T.S., Yeh J.W., Chen S.K., Mater. Sci. Eng. A, 2011, 528, 3581; doi 10.1016/j.msea.2011.01.072

58. Tsai M.H., Wang C.W., Tsai C.W., Shen W.J., Yeh J.W., Gan, J.Y., Wu W.W., J. Electrochem. Soc., 2011, 158, H1161; doi 10.1149/2.056111jes

59. Chou Y.L., Wang Y.C., Yeh J.W., Shih H.C., Corros. Sci., 2010, 52, 3481; doi 10.1016/j.corsci.2010.06.025

60. The American Institute of Physics Handbook, Gray D.E. (Ed.), McGraw-Hill, New York, 1972.

61. Arblaster J.W., Platin. Met. Rev., 1996, 40, 62.

62. Konti A., Varshni Y.P., Can. J. Phys., 1969, 47, 2021; doi 10.1139/p69-255 


\section{Ab initio дослідження структурних електронних і теплових властивостей сплавів $\operatorname{Ir}_{1-x} \mathrm{Rh}_{x}$ alloys}

\section{Ш. Ахмед, М. Зафар, М. Шакіл, М.А. Чоуджарі}

Лабораторія комп'ютерного моделювання, фізичний факультет, Ісламський університет м. Бахавалпур, м. Бахавалпур 63100, Пакистан

Структурні, електронні, механічні і теплові властивості сплавів $\operatorname{Ir}_{1-x} \mathrm{Rh}_{x}$ систематично досліджено з використанням ab initio теорії функціоналду густини при різних концентраціях $(x=0.00,0.25,0.50,0.75$, 1.00). Було використано метод спеціальної квазівипадкової структури для моделювання сплавів, що мають структуру FCC з чотирма атомами на одиничну комірку. Були обчислені властивості основного стану, такі як постійна ґратки та об'ємний модуль пружності, для того, щоб знайти рівноважні положення атомів для стійких сплавів. Обчислені властивості основного стану добре узгоджуються з експериментальними та іншими раніше отриманими теоретичними даними. 3 метою вивчення електронних властивостей цих сплавів при різних концентраціях обчислено електронну зонну структуру та густину станів. Електронні властивості обгрунтовують металічну поведінку сплавів. Для обчислення теплових характеристик була використана першопринципна теорія збурень функціоналу густини, імплементована у квазігармонічне наближення. Нами обчислено такі теплові характеристики, як температура Дебая, енергія коливань, ентропія, питома теплоємність при постійному об'ємі та внутрішня енергія. Було використано ab initio метод лінійного відгуку для обчислення густини станів фононів.

Ключові слова: електронні, стактурні і теплові властивості металів платинової групи 